Historic, Archive Document

Do not assume content reflects current scientific knowledge, policies, or practices. 

A 99.9 F 7632 Us

iouthwest

Plains
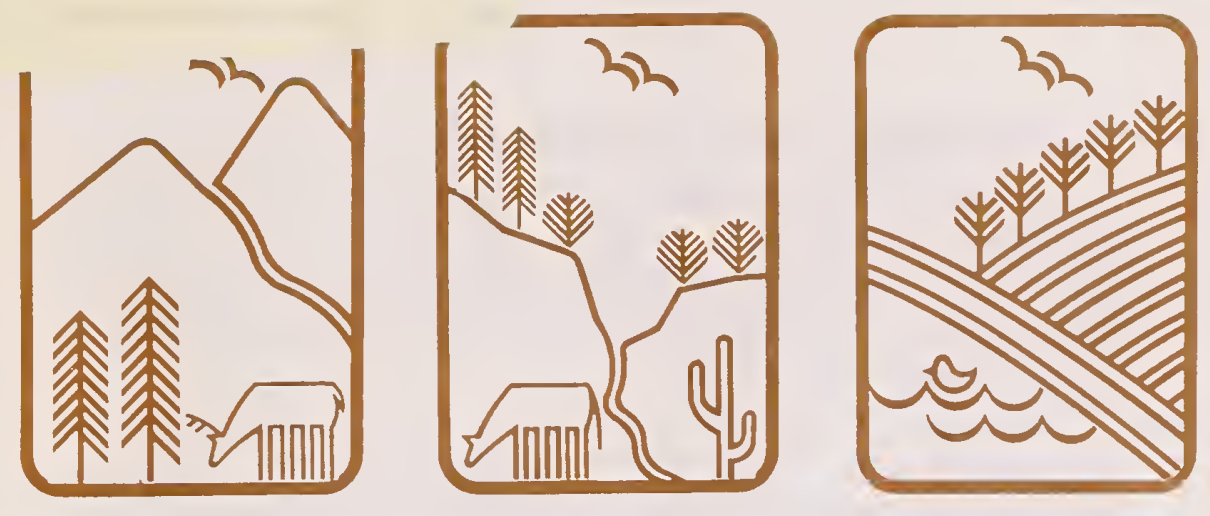

February 1988

USDA Forest Service

Rocky Mountain Forest and Range Experiment Station

\title{
Natural Production Potential of Some Rio Puerco Soils in New Mexico ${ }^{1}$
}

\author{
Earl F. Aldon, David G. Scholl, P. R. Fresquez, \\ and Richard E. Francis ${ }^{2}$
}

Soils from six representative plant communities on the upper Rio Puerco Watershed in New Mexico were sampled and tested for inherent production capability. Tests included leaf area and dry weight of greenhouse grown barley (Hordium vulgare var. Arivat), soil chemical/ physical properties, dehydrogenase activity, and plant community herbaceous production. There was no difference between inherent production capability of the soils based on barley leaf area and dry weight; barley leaf area was correlated to soil chemical properties and herbaceous production was correlated with plant communities.

Keywords: soil capability, dehydrogenase, bioassay, Rio Puerco, New Mexico.

Quantification and description of plant communities provides a way to categorize land units having similar environments and biotic potentials, and which can be expected to respond similarly to disturbance. This note examines natural productivity of some soils which were identified on the Rio Puerco watershed (Francis 1986). The soil and climatic characteristics of these plant communities will determine their natural productivity. Management practices have altered these conditions, and can be used to improve future productivity.

\section{Study Area and Methods}

The Upper Rio Puerco Watershed, in northwestern New Mexico, was classified into 45 ecological phytoedaphic communities using cluster analysis based on species importance values (Francis 1986). The combination of landform, vegetation and soil was used to classify phyto-edaphic communities.

A review of the 45 communities on the Rio Puerco watershed showed six plant communities occurring most frequently.

${ }^{1} T$ This research reported here was conducted in cooperation with the USDI Bureau of Land Management which furnished funds and field study locations.

${ }^{2}$ Aldon is Research Forester, Scholl is Soil Scientist, Fresquez is Soil Microbiologist, and Francis is Range Scientist, Rocky Mountain Forest and Range Experiment Station, at the Station's Research Work Unit in Albuquerque, N. Mex. Station headquarters is in Fort Collins, in cooperation with Colorado State University.

\begin{tabular}{|c|c|c|}
\hline $\begin{array}{l}\text { Plant } \\
\text { community } \\
\text { number }\end{array}$ & Name & $\begin{array}{l}\% \text { of } \\
\text { total }\end{array}$ \\
\hline 6 & $\begin{array}{l}\text { Juniperus monosperma/ } \\
\text { Gutierrezia sarothrae/ } \\
\text { Bouteloua gracilis- } \\
\text { Hilaria jamesii } \\
\text { (Jumo/Gusa/Bogr-Hija) }\end{array}$ & 11 \\
\hline 9 & $\begin{array}{l}\text { Artemisia tridentata/ } \\
\text { Bouteloua gracilis- } \\
\text { Hilaria jamesii } \\
\text { (Artr/Bogr-Hija) }\end{array}$ & 5 \\
\hline 13 & $\begin{array}{l}\text { Artemisia tridentata- } \\
\text { Gutierrezia sarothrae/ } \\
\text { Bouteloua gracilis- } \\
\text { Agropyron smithii } \\
\text { (Artr-Gusa/Bogr-Agsm) }\end{array}$ & 16 \\
\hline 18 & $\begin{array}{l}\text { Chrysothamnus nauseosus } \\
\text { spp. bigelovii/Bouteloua } \\
\text { gracilis-Agropyron smithii } \\
\text { (Chnab/Bogr-Agsm) }\end{array}$ & 7 \\
\hline 32 & $\begin{array}{l}\text { Gutierrezia sarothrae/ } \\
\text { Bouteloua gracilis-Hilaria } \\
\text { jamesii (Gusa/Bogr-Hija) }\end{array}$ & 8 \\
\hline 42 & $\begin{array}{l}\text { Gutierrezia sarothrae/ } \\
\text { Sporobolus airoides-Hilaria } \\
\text { jamesii (Gusa/Spai-Hija) }\end{array}$ & 6 \\
\hline
\end{tabular}

Total $53 \%$ 
Each plant community contained from three to twentyone 180-m Community Structural Analysis (CSA) transects installed in 1979. The CSA technique includes measurement for litter, bare soil, diversity and, by plant species, foliar cover, density, frequency, and Importance Values (Pase 1981). Each transect was given a community description based on 7 years of data collection (Francis 1986). Also, at each transect and to the side, herbaceous production measurements were taken for each study year (Schumacher and Chapman 1948).

Because each plant community (PC) was found on several soil series, only transects that contained mediumtextured soils were selected, to minimize variability in this study. These textures consisted of sandy loam, loam, sandy clay loam, and clay loam. At each of the selected transects (5 transects per plant community), three soil subsamples were collected randomly along the length of the transect line to a depth of $15 \mathrm{~cm}$, using a $5 \mathrm{~cm}$ (diameter) bucket auger. The three subsamples were mixed thoroughly in a sterile plastic bag, and were cooled immediately in an ice-chest. At the laboratory, the samples were passed through a $2-\mathrm{mm}$ sieve and were stored at $4{ }^{\circ} \mathrm{C}$. An aliquot from each sample was taken for laboratory analyses at the New Mexico State University Soil and Water Testing Laboratory. The soluble cations were determined by atomic absorption. Available phosphorus was determined by Olson's procedure using $\mathrm{NaHCO}_{3} ; \mathrm{NH}_{4}-\mathrm{N}$ was determined colorimetrically (from a 1:5 soil/KC1 extract), and $\mathrm{NO}_{3}-\mathrm{N}$ was determined by $\mathrm{Cd}$ reduction (from a 1:5 soil/water extract). Total nitrogen was determined by the micro-Kjeldahl procedure (TKN). Organic matter was determined by the Walkley-Black procedure (Allison 1965) and the hydrometer method was used to determine texture (USDA 1972).

In addition to the standard soil analysis conducted on each transect, additional sampling was done. Using methods previously described, soil samples were collected along the same transects and were taken to the laboratory to estimate biological activity in the soils as measured by the dehydrogenase method (Skujins 1973), and for a productivity study using barley. Dehydrogenase is a general indicator of microbial activity, and barley plants are commonly used in bio-assay tests of agronomic soil fertility (Campbell 1968).

The cumulative effects of the soil properties enhancing plant growth are readily visible using barley plants under controlled conditions. In such studies, climate, soil texture, and moisture conditions are constant, in contrast to wide variations of these variables under field conditions.

In this study, barley plants were used as indicators of plant response to unamended soil fertility under optimum moisture conditions. Ninety, 3.8-L plastic nursery pots were lined with paper toweling to retain the soil and were filled with soil from each transect. There were three replications of each soil (e.g., medium textured soils $=3$ reps $\times 6$ plant communities $\times 5$ transects $=$ 90 pots).

Ten barley seeds were planted $6 \mathrm{~mm}$ deep in each pot and were thinned to 5 seedlings after 10 days. Pots were watered with $1,200-\mathrm{mL}$ of distilled water initially and $100-\mathrm{mL}$ of distilled water every other day, to maintain optimum moisture conditions for the 37 days of the study. The greenhouse temperatures were kept at $27^{\circ} \mathrm{C}$ day and $19^{\circ} \mathrm{C}$ night. No artificial light was used during October and November.

The barley plants were harvested after 37 days and immediately were placed under a leaf area meter and a composite of leaf area derived for the five plants in each pot. Plant samples then were oven dried for 48 hours at $70^{\circ} \mathrm{C}$, were weighed and sent to New Mexico State University Plant and Soils Lab for nutrient analysis (percent P, K, $\mathrm{Ca}, \mathrm{Na}$, and ppm of Fe; samples were too small for TKN analysis). The three replicate pots were averaged to obtain response measurements for each transect.

A series of analyses was used to determine if the soils from the six plant communities selected had inherently different natural production capabilities. Analysis of "productive capability" took different forms.

To evaluate barley response to soil conditions (and, therefore, suitability as indicator of fertility or potential productivity) barley leaf area and dry weight were compared to the soil measurements.

Barley leaf area and field estimates of production, cover, density, and dehydrogenase activity were compared among plant communities using one-factor analysis of variance. Significant overall tests of variation among soils were followed using least significant difference analysis of pairwise differences between plant communities.

\section{Results and Discussion}

Because this analysis included only medium-textured soils, there were no significant differences in textures among the soils representing each of the plant communities (table 1). In contrast, each plant community had at least one or more chemical properties that were significantly different from each other (table 1). For example, soil from plant community 42 had significantly higher $\mathrm{Na}$ and SAR values compared to the soils from most of the other plant communities. Soil $\mathrm{P}, \mathrm{NO}_{3}-\mathrm{N}$, and TKN was significantly higher in plant community 13 compared to one or two of the other plant communities. Organic matter contents ranged from a low of $0.61 \%$ in the soil from plant community 32 to a significantly higher $1.15 \%$ in the soil from plant community 9. Soil from plant community 13 had a significantly lower $\mathrm{pH}$ value than all the other communities.

Barley leaf area was only moderately correlated to soil properties, based on correlation analysis when all communities were combined. Positive correlations between leaf area and organic matter, $\mathrm{P}, \mathrm{K}$, and total $\mathrm{N}$ were observed (table 2). Other properties, such as EC and SAR, had negative correlations; but none were significant.

When barley leaf area was compared between soils of the plant communities, none were significantly different. If, as indicated above, barley is a reasonable indicator of soil fertility, then the plant communities were not closely related to soil fertility usually encountered in agricultural systems. 
Table 1.-Chemical and physical properties associated with soils from six semi-arid plant communities.

\begin{tabular}{|c|c|c|c|c|c|c|c|c|c|c|c|c|c|c|c|}
\hline \multirow{2}{*}{$\begin{array}{l}\text { Plant } \\
\text { community }\end{array}$} & \multicolumn{4}{|c|}{ Soluble cations } & \multicolumn{4}{|c|}{ Phosphorus and nitrogen } & \multirow{2}{*}{$\begin{array}{l}\text { Organic } \\
\text { matter }\end{array}$} & \multirow[b]{2}{*}{$\mathrm{pH}$} & \multirow[b]{2}{*}{ EC } & \multirow[b]{2}{*}{ SAR } & \multirow[b]{2}{*}{ Sand } & \multirow[b]{2}{*}{ Silt } & \multirow[b]{2}{*}{ Clay } \\
\hline & $\mathrm{Na}$ & $\mathrm{Ca}$ & Mg & $\mathrm{K}$ & $P$ & $\mathrm{NH}_{4} \cdot \mathrm{N}$ & $\mathrm{NO}_{3} \cdot \mathrm{N}$ & TKN & & & & & & & \\
\hline & ----- & --- meq & $L^{-1}$ & ----- & ------ & -----1 & pm --- & ----- & $\%$ & & $\mathrm{dSm}^{-1}$ & & ---- & $\%$ & --- \\
\hline 6 Jumo/Gusa/ & $0.81 b^{1}$ & & & & & & & & & & & & & & \\
\hline $\begin{aligned} 9 \text { Artr/Bogr-Hija } \\
13 \text { Artr-Gusa/ }\end{aligned}$ & $0.57 \mathrm{~b}$ & $\begin{array}{l}2.7 / \mathrm{ab} \\
3.65 \mathrm{ab}\end{array}$ & $\begin{array}{l}0.93 \\
0.71\end{array}$ & $\begin{array}{l}0.43 a b \\
0.27 a b\end{array}$ & $\begin{array}{l}2.0 \mathrm{c} \\
5.0 \mathrm{ab}\end{array}$ & $\begin{array}{l}2.49 \\
3.26\end{array}$ & $\begin{array}{l}1.82 \mathrm{ab} \\
2.20 \mathrm{ab}\end{array}$ & $\begin{array}{l}625 a b \\
620 a b\end{array}$ & $\begin{array}{l}0.95 a b \\
1.15 a\end{array}$ & $\begin{array}{l}.66 \mathrm{a} \\
7.50 \mathrm{a}\end{array}$ & $\begin{array}{l}0.48 a b \\
0.48 a b\end{array}$ & $0.40 \mathrm{~b}$ & $\begin{array}{l}53 \\
56\end{array}$ & $\begin{array}{l}23 \\
19\end{array}$ & $\begin{array}{l}25 \\
25\end{array}$ \\
\hline $\begin{array}{ll}\text { Bogr-Agsm } \\
18 \text { Chnab/Bogr- }\end{array}$ & $1.98 b$ & $1.62 b$ & 0.43 & $0.13 b$ & $5.1 \mathrm{a}$ & 3.80 & $4.06 a$ & $807 a$ & $1.05 a b$ & $7.04 b$ & $0.40 \mathrm{~b}$ & $2.51 b$ & 51 & 23 & 26 \\
\hline Agsm & $1.05 b$ & $2.84 a b$ & 0.91 & $0.64 a$ & $2.7 a b c$ & 3.74 & $2.84 a b$ & $756 a$ & $0.96 a b$ & $7.67 a$ & $0.50 \mathrm{ab}$ & $0.78 b$ & 53 & 22 & 25 \\
\hline 32 Gusa/Bogr-Hija & $0.75 b$ & $3.85 a b$ & 0.94 & $0.36 a b$ & $2.2 \mathrm{bc}$ & 1.96 & $1.24 b$ & $700 a$ & $0.61 b$ & $7.83 a$ & $0.53 a b$ & $0.51 b$ & 52 & 25 & 23 \\
\hline 42 Gusa/Spai-Hija & $7.09 a$ & $8.63 a$ & 0.86 & $0.37 a b$ & $2.7 a b c$ & 2.57 & $2.20 a b$ & $462 b$ & $0.65 a b$ & $7.70 \mathrm{a}$ & $1.41 \mathrm{a}$ & $7.62 a$ & 47 & 25 & 28 \\
\hline
\end{tabular}

${ }^{1}$ Means within the same column followed by the same letter are not significantly different at the 0.05 level according to the F-protected Least Significant Difference (L.S.D.) test.

Table 2.-Pearson's correlation coefficients for barley leaf area and abiotic variables associated with soils from six plant communities.

\begin{tabular}{lc}
\hline Soil properties & Correlation coefficients \\
\hline Organic matter & $0.38^{*}$ \\
P & $0.41^{*}$ \\
$\mathrm{~K}$ & $0.40^{*}$ \\
TKN & $0.57^{*}$ \\
$\mathrm{EC}$ & -0.23 \\
$\mathrm{SAR}$ & -0.07 \\
$\mathrm{pH}$ & -0.18 \\
$\mathrm{Na}$ & -0.16 \\
$\mathrm{Ca}$ & -0.25 \\
$\mathrm{Mg}$ & -0.25 \\
$\mathrm{NO}{ }^{-} \mathrm{N}$ & -0.01 \\
$\mathrm{NH} \cdot \mathrm{N}$ & 0.14 \\
$\mathrm{Sand}$ & -0.27 \\
Silt & 0.33 \\
Clay & -0.00 \\
\hline
\end{tabular}

*Significant at $5 \%$ significance level.

Table 3.-Average annual forage production (all years) by plant communities.

\begin{tabular}{lccc}
\hline Plant community & $\begin{array}{c}\text { Mean forage } \\
\text { lb/ac }\end{array}$ & Std. dev. & \\
\hline 6 Jumo/Gusa/Bogr-Hija & 396.4 & 54.6 & $\mathrm{a}^{1}$ \\
18 Chnab/Bogr-Agsm & 340.9 & 42.2 & $\mathrm{~b}$ \\
32 Gusa/Bogr-Hija & 335.7 & 37.2 & $\mathrm{~b}$ \\
42 Gusa/Spai-Hija & 311.6 & 28.6 & $\mathrm{~b}$ \\
9 Artr/Bogr-Hija & 250.6 & 43.5 & $\mathrm{C}$ \\
13 Artr-Gusa/Bogr-Agsm & 171.5 & 33.8 & $\mathrm{~d}$ \\
\hline
\end{tabular}

${ }^{1}$ Different letters in the column indicate significant differences at the 0.05 level according to the F-protected L.S.D. test.
Table 4.-Plant communities vs. average transect cover values (all years).

\begin{tabular}{lccl}
\hline Plant community & Mean cover \% & Std. dev. & \\
\hline 6 Jumo/Gusa/Bogr-Hija & 33.3 & 9.5 & $\mathrm{ab}^{1}$ \\
9 Artr/Bogr-Hija & 32.5 & 7.5 & $\mathrm{abc}$ \\
13 Artr-Gusa/Bogr-Agsm & 29.2 & 7.3 & $\mathrm{bc}$ \\
18 Chnab/Bogr-Agsm & 40.4 & 10.6 & $\mathrm{a}$ \\
32 Gusa/Bogr-Hija & 29.5 & 5.0 & $\mathrm{bc}$ \\
42 Gusa/Spai-Hija & 24.5 & 6.6 & $\mathrm{c}$ \\
\hline
\end{tabular}

${ }^{1}$ Different letters in the column indicate significant differences at the 0.05 level according to the F-protected L.S.D. test.

Table 5._Plant communities vs. transect density values (all years).

\begin{tabular}{lccl}
\hline Plant community & $\begin{array}{c}\text { Mean density } \\
\text { plants/0.5 } \text { m }^{2}\end{array}$ & Std. dev. & \\
\hline 18 Chnab/Bogr-Agsm & 83.9 & 26.7 & $\mathrm{a}^{1}$ \\
32 Gusa/Bogr-Hija & 65.2 & 23.1 & ab \\
13 Artr-Gusa/Bogr-Agsm & 59.9 & 25.3 & $\mathrm{~b}$ \\
6 Jumo/Gusa/Bogr-Hija & 56.9 & 20.5 & $\mathrm{~b}$ \\
9 Artr/Bogr-Hija & 47.9 & 26.6 & $\mathrm{~b}$ \\
42 Gusa/Spai-Hija & 39.4 & 10.4 & $\mathrm{C}$ \\
\hline
\end{tabular}

${ }^{1}$ Different letters in the columns indicate significant differences at the 0.05 level according to the F-protected L.S.D. test.

Table 6.-Dehydrogenase activity associated with soils from six semiarid plant communities.

\begin{tabular}{lc}
\hline Plant community & Dehydrogenase activity \\
\hline & $\mu \mathrm{g}$ Formazan $\mathrm{g}^{-1} \mathrm{~d}^{-1}$ \\
32 Gusa/Bogr-Hija & $23 \mathrm{a}^{1}$ \\
6 Jumo/Gusa/Bogr-Hija & $18 \mathrm{ab}$ \\
42 Gusa/Spai-Hija & $17 \mathrm{~b}$ \\
18 Chnab/Bogr-Agsm & $15 \mathrm{~b}$ \\
9 Artr/Bogr-Hija & $15 \mathrm{~b}$ \\
13 Artr-Gusa/Bogr-Agsm & $12 \mathrm{~b}$ \\
\hline
\end{tabular}

${ }^{1}$ Means within the same column followed by the same letter are not significantly different at the 0.05 level according to the $F$-protected Least Significant Difference (L.S.D.) test. 
An analysis of the herbaceous production data for 1985 among plant communities showed significant differences in three communities (communities 6, 9, and 13). These preliminary results suggested that further analysis using production for all years was worth testing against plant communities. For example, when the average of all years of herbage production from transect data was tested among plant communities, significant differences among plant communities were apparent (table 3). Plant community 6 was significantly higher in herbage production than the other plant communities, with 18 second; 32,42 , and 9 the same; and 13 the poorest producer (table 3).

A test of plant communities vs. percent cover as measured on the transects for the average of all years showed that plant community 18 was significantly different from 42,32 , and 13, and 6 significantly different than 42 (table 4).

A test of plant communities vs. plant density, as measured on the transects for the average of all years, showed that plant community 18 was significantly different from $42,9,13$, and 6 , and 42 , different from the rest (table 5).

Dehydrogenase activity ranged from 12 to $23 \mu \mathrm{g}$ formazan $\mathrm{g}^{-1} \mathrm{~d}^{-1}$ in the soil (table 6). Soil from plant community 32 was significantly higher in dehydrogenase activity compared to four of the other plant communities. Soil from plant community 13 had the lowest dehydrogenase activity, which correlates well with the lower plant production values obtained from the field transect data.

\section{Conclusions}

Field measurements of productivity vary among plant communities. Herbaceous production, foliar cover, and density values of Jumo/Gusa/Bogr-Hija (6) and Chnab/ Bogr-Agsm (18) plant communities were the most productive communities evaluated. Herbage production averaged between 340 and $400 \mathrm{lb} / \mathrm{A}$. The Gusa/Spai-Hija (42) and Artr-Gusa/Bogr-Hija (13) plant communities have much less production and also low cover and density values.
Neither leaf area nor dry weight of barley was able to differentiate differences in inherent productivity among these unamended soils from these six plant communities. The barley tests showed that, under optimum moisture condition, inherent productivity does not vary among the soils of the selected plant communities.

The next steps in the research process are to identify possible causes for field variation in productivity.

\section{Literature Cited}

Allison, L. E. 1965. Organic carbon. In: C.A. Black, D.D. Evans, J.L. White, L.E. Ensminger and F.E. Clark (editors), Methods of Soil Analysis, Part 2. Agronomy. American Society of Agronomy, Madison, WI, pp. 1367-1378.

Campbell, R. E. 1968. Production capabilities of some Upper Rio Puerco soils of New Mexico, USDA Forest Service Research Note RM-108, 7 p. Rocky Mountain Forest and Range Experiment Station, Fort Collins, Colorado.

Francis, Richard E. 1986. Phyto-edaphic communities of the Upper Rio Puerco Watershed, New Mexico. USDA Forest Service Research Paper RM-272, 73 p. Rocky Mountain Forest and Range Experiment Station, Fort Collins, Colo.

Pase, C.P. 1981. Community stucture analysis-a rapid, effective range condition estimator for semi-arid ranges. p. 425-430. In: Arid land resource inventories: Developing cost-efficient methods. [Nov. 30 - Dec. 6, 1980, LaPaz, Mexico]. H. G. Lund, et al. tech. coord. USDA Forest Service General Technical Report WO-28, 620 p. Washington, D.C.

Schumacher, F. X. and R. A. Chapman 1948. Sampling methods in forestry and range management. Duke Univ. School of For. Bul. 7, Revised. 222 p.

Skujins, J. J. Dehydrogenase: An indicator of biological activities in arid soils. Bulletin Ecological Research Committee (Stockholm), 17:235-241, 1973.

U.S. Department of Agriculture, 1972. Soil Survey Laboratory Methods and Procedures for Collection Soil Samples. Soil Conservation of America, Soil Survey Investigation Report No. 1, U.S. Government Printing Office, Washington, D.C. 